International Research Journal of Management, IT \& Social Sciences
Available online at https://sloap.org/journals/index.php/irjmis/
Vol. 6 No. 5, September 2019, pages: 158 166
ISSN: 2395-7492
https://doi.org/10.21744/irjmis.v6n5.713

\title{
Job Satisfaction Mediating towards Effect of Emotional Intelligence on Performance
}

Ida Ayu Putri Widya Lestari ${ }^{\text {a }}$ I Made Artha Wibawa ${ }^{b}$

Article history:

Received: 27 March 2019

Accepted: 31 May 2019

Published: 28 August 2019

\section{Keywords:}

emotional intelligence;

implication;

job satisfaction;

performance;

produce;

\begin{abstract}
The study was conducted at BBPOM in Denpasar. The number of samples used was as many as 90 people using the saturated sample selection method. Data collection using a questionnaire that uses a Likert scale. Data analysis techniques were performed using structural equation modeling with a partial least square approach and using the VAF test to test the role of mediation. The results showed that emotional intelligence had a significant positive effect on employee performance at BBPOM in Denpasar with a path coefficient of 0.469. Job satisfaction is known to partially mediate the relationship of emotional intelligence to employee performance at BBPOM in Denpasar. The findings in this study provide the implication that to produce good performance in order to achieve excellent service, it is necessary to have activities in the form of training related to emotional intelligence and job satisfaction that can effectively improve employee skills to have an understanding and sensitivity to emotions of themselves and others, so that employees can deal well with all forms of organizational life dynamics and show maximum performance to achieve excellent service.
\end{abstract}

2395-7492@ Copyright 2019. The Author.

This is an open-access article under the CC BY-SA license (https://creativecommons.org/licenses/by-sa/4.0/) All rights reserved.

Author correspondence:

Ida Ayu Putri Widya Lestari,

Faculty of Economic and Business Udayana University, Denpasar, Indonesia.

Email address: widyalestariidaayuputri@gmail.com

\section{Introduction}

The analysis of the strategic environment contained in the Strategic Plan of the Center for Drug and Food Supervision in Denpasar in 2015-2019, said there was still a need to increase competency (capacity building) in several ASNs which became a point in the SWOT analysis conducted. Described in the analysis of problems and conditions at BBPOM in Denpasar according to their duties, functions, and authorities, shows that BPOM's prime public service is not optimal (BBPOM in Denpasar, 2015). The human resource aspect is one of the indicators assessed in the performance appraisal, in particular, the evaluation of public service delivery units within the Food and Drug

a Udayana University, Denpasar, Indonesia

${ }^{\mathrm{b}}$ Udayana University, Denpasar, Indonesia 
Supervisory Agency. The results of the evaluation of public service providers at the Central Food and Drug Supervisory Agency in Denpasar by the POM in 2019, showed that public services at BBPOM in Denpasar have not yet reached the prime service category.

Based on interviews and observations on preliminary research conducted on several employees at BBPOM in Denpasar, some employees were known to feel unable to motivate themselves in their work, pessimism about their abilities, as well as the quantity and type of work that often did not match competence. This is felt to affect the process of work such as the occurrence of errors in the completion of work until the time of work completion. The objective condition of the achievements described shows that BBPOM in Denpasar as a technical implementing unit (UPT) of POM still requires the arrangement and strengthening of the roles, main tasks, and functions so that future performance achievement is getting better and optimal. From these conditions, it indicates that the performance in the form of excellent service in the BBPOM environment in Denpasar has not been achieved optimally and there are several problems that can affect employee performance.

Based on the literature studied, one of the factors that can influence the emergence of these problems is emotional intelligence. Some employees, in interviews and observations in the initial research at BBPOM in Denpasar, showed that it was difficult to control or have good control over one's own emotions when under pressure or difficult conditions at work. Emotional intelligence is essentially identical to the ability to effectively manage one's emotions (Jeon, 2016). Individual success in organizational management according to Dulewicz \& Higgs (2000), is contributed by $16 \%$ by managerial intelligence, $27 \%$ by IQ, and $36 \%$ by emotional intelligence. Cherniss (2000) suggests that a person's ability to understand, identify, and manage emotions provides the basis for social and emotional competencies that are essential for success in almost all types of work. This implies that job performance is largely determined by competencies related to emotional intelligence (Chaudhry \& Usman, 2011; Chanana \& Gupta, 2016; Farrastama et al., 2019). In line with this statement, Curseu et al., (2016) in Jamshed (2018), stated that high-performance teams have better emotional competence and experience less conflict than teams that are less emotionally intelligent.

The relevance of emotional intelligence to the effectiveness of performance shows a positive correlation. Emotional competence factors are known to be the main contributing factors to performance, compared to two other emotional intelligence factors, emotional maturity and emotional sensitivity (Mishra \& Mohapatra, 2010). The impact of emotional intelligence on performance in a study conducted by Rangarajan \& Jayamala (2014), shows that emotional intelligence is positively correlated with performance. Employee performance increases with increasing emotional intelligence. Studies on the dynamics of emotional intelligence in company employees also show that there is a positive correlation between emotional intelligence and performance (Narayana \& Narasimham, 2018; Kawiana et al., 2018; Kurniawan, 2019). Based on the description of several studies above, it can be concluded that employee performance can be positively influenced by emotional intelligence. Some previous studies mention that the influence of emotional intelligence on performance can be influenced by job satisfaction variables. Barakat (2015) in Theresia et al., (2018), explains that job satisfaction basically refers to how much employees like their work. Job satisfaction will arise if individuals like their work, and there will be dissatisfaction in the members of the organization if they do not like their work. This is an attitude or emotional response to work tasks, which is simultaneous to the social and physical conditions at work. When individuals feel excessive stress, they tend to be less satisfied and produce worse performance. Research conducted on employees who work in the information technology sector shows that an employee's ability to manage the emotions and emotions of others and satisfied employees have a high commitment to their work and organization. There are indirect effects of emotional intelligence on performance. As an important factor for optimizing job performance, job satisfaction will have a constructive effect when followed by an increase in employee emotional intelligence. In other words, if emotional intelligence can affect job satisfaction, and job satisfaction can affect employee performance, there is the potential for job satisfaction to be able to act as a mediator between emotional intelligence and performance.

There are still few studies that try to test the mediating effect of job satisfaction on emotional intelligence and performance. The study of employee emotional intelligence will be very important to be carried out for agencies implementing public services that can help them in designing various policies related to the development of human resource management. Based on the phenomena and empirical studies described above, this study aims to examine the influence of emotional intelligence on performance at BBPOM in Denpasar and how job satisfaction mediates the relationship between the two.

Lestari, I. A. P. W., \& Wibawa, I. M. A. (2019). Job satisfaction mediating towards effect of emotional intelligence on performance. International Research Journal of Management, IT and Social Sciences, 6(5), 158-166. https://doi.org/10.21744/irjmis.v6n5.713 


\section{Literature Review and Hypothesis}

The issue of improving productivity through improved performance is now the focus of almost all organizations. A thorough analysis of organizational performance is needed to be able to understand employee performance and the factors inherent to them individually. The framework of thinking that underpins this research is one of the main assets of the organization, it is important to understand the performance of employees in the organization individually to be able to optimize overall organizational performance. Performance is the behavior displayed by employees in the workplace that gives the desired results by the organization related to quality, quantity and work time. Employee performance itself is seen as an indicator of employee efficiency and productivity, as well as the long-term success of an organization (Na-Nan \& Chaiprasit, 2018; Pant \& Yadav, 2016; Saputra et al., 2019).

Based on interviews and observations on preliminary research studies on employees at BBPOM in Denpasar, some employees are known to feel unable to motivate themselves at work, pessimism about their abilities, as well as the quantity and type of work that is often incompatible with competence. This is felt to affect the process of working, such as the occurrence of errors in the completion of work until the completion of work that is not appropriate. BBPOM's Strategic Plan in Denpasar in 2015-2019 contains the results of a strategic environmental analysis which states that there is still a need to improve competence at ASN. Analysis of the problems and conditions illustrates that BBPOM public services in Denpasar have not yet achieved excellent service. Higher employee performance can be achieved by emotionally intelligent individuals (Chaudhry \& Usman, 2011).

The effect of emotional intelligence on leaders and subordinates on performance and attitudes shows that it is generally believed that individuals with high levels of emotional intelligence are better workers (Wong \& Law, 2002). Curseu et al., (2016), stated that high-performance teams have better emotional competence and experience less conflict than teams that are less emotionally intelligent (Jamshed, 2018). It is believed that there is a positive correlation between emotional intelligence and performance. Employee performance will increase with increasing emotional intelligence (Rangarajan \& Jayamala, 2014; Narayana \& Narasimham, 2018).

When employees feel comfortable or like a job that suits themselves, it will tend to cause satisfaction. The existence of satisfaction or vice versa is a form of simultaneous emotional response to social conditions and physical conditions at work (Theresia et al., 2018). Employees who have the ability to manage emotions, as well as employees who are satisfied have a high commitment to the work and organization. If emotional intelligence can affect job satisfaction, and job satisfaction can affect employee performance, there are potential indirect effects or in other words job satisfaction can act as a mediator between emotional intelligence and performance (Vratskikh et al., 2016; Yoke \& Panatik, 2016; Widiani et al., 2019; Wiguna \& Yadnyana, 2019).

\section{Hypothesis}

H1 : Emotional intelligence has a positive and significant effect on employee job satisfaction

$\mathrm{H} 2$ : Emotional intelligence has a positive and significant effect on employee performance

H3 : Job Satisfaction has a positive and significant effect on employee performance

H4: Job Satisfaction positively and significantly mediates the effect of Emotional Intelligence on Employee Performance

\section{Materials and Methods}

The population used in this study were all employees with ASN status in the BBPOM in Denpasar on 90 respondents. The sampling technique uses the saturation sampling method. Saturated sampling is a sampling technique where all members of the population are used as samples. The method used in this research is a cross-sectional survey method which in gathering data uses a questionnaire or a structured questionnaire related to the research variables. The variables used in this study are emotional intelligence as an exogenous variable, and job performance and satisfaction as an endogenous variable. The analysis used in this research is a quantitative analysis using Structural Equation Modeling (SEM) with Partial Least Square (PLS) approach. 


\section{Results and Discussions}

An evaluation of the structural model or inner model is carried out to ensure that the structural model that is constructed is robust and accurate. Testing can be done by calculating the value of $\mathrm{R}$ square $\left(\mathrm{R}^{2}\right)$ and predictive relevance $\left(Q^{2}\right)$.

Table 1

R Square

\begin{tabular}{ll}
\hline Variable & R Square \\
\hline Job Satisfaction (M) & 0.467 \\
Performance (Y) & 0.725 \\
\hline Primary Data 2019
\end{tabular}

Primary Data, 2019

In table 1 it can be seen that the $\mathrm{R}$ square value of the performance variable is 0.725 . This value can explain that $72.5 \%$ of changes in performance variables are quite strongly influenced by variables of emotional intelligence and job satisfaction, while $27.5 \%$ of changes are influenced by variables outside the model. On the job satisfaction variable, $46.7 \%$ of the change is influenced by emotional intelligence variables, and $53.3 \%$ is influenced by variables outside the model.

Based on the acquisition of $\mathrm{R} 2$, a calculation can be made of the value of predictive relevance (Q2), with interpretation if Q2 is greater than 0, then the model can be said to be good and able to explain the phenomenon of performance variables equal to the Q2 value. Predictive relevance values can be calculated as follows:

$$
\begin{aligned}
Q^{2} & =1-\left(1-{R_{1}}^{2}\right)\left(1-{R_{2}}^{2}\right) \\
& =1-(1-0,725)(1-0,467) \\
& =1-(0,275)(0,533) \\
& =1-(0,146) \\
& =0,853
\end{aligned}
$$

The results of this calculation indicate that the Q2 value is greater than $0(0.853)$, so the model can be said to be good and has a relevant predictive value of $85.3 \%$. This value interprets that $85.3 \%$ of changes or variations in performance variables can be explained by the variables used in the study, while the remaining $14.7 \%$ is explained by other variables outside the model.

\section{Hypothesis testing result}

The significance of the estimated parameters can be used to see the relationship between variables in the study. To test the hypothesis, this is done by looking at the values in the path coefficients presented in Table 2 below:

Table 2

Path Coefficients

\begin{tabular}{lllll}
\hline \multirow{2}{*}{ Variable } & Path & $t$ & $\mathrm{p}$ & \multirow{2}{*}{ Description } \\
\hline Emotional intelligence -> Job Satisfaction & Coefficients & Statistics & Values & (683 \\
Emotional intelligence -> Performance & 0,469 & 8,061 & 0,000 & Accepted \\
Job Satisfaction -> Performance & 0,459 & 2,799 & 0,005 & Accepted \\
\hline
\end{tabular}

Primary Data, 2019

Hypothesis testing is evaluated by looking at the t-statistic value, as well as the p-value. At the condition of t-statistic greater than t-table (1.96), and p-value below 0.05 , the research hypothesis can be accepted. In Table 2 , it is known that the influence of emotional intelligence $(\mathrm{X})$ on job satisfaction $(\mathrm{M})$ has a t-statistic value of 8.061 and a p-value of 0.000 , then there is a positive and significant effect between emotional intelligence $(\mathrm{X})$ and job satisfaction $(\mathrm{M})$. Next the influence of emotional intelligence $(\mathrm{X})$ on performance $(\mathrm{Y})$ has a t-statistic value of 2.799 and $\mathrm{p}$-value of 0.005 ,

Lestari, I. A. P. W., \& Wibawa, I. M. A. (2019). Job satisfaction mediating towards effect of emotional intelligence on performance. International Research Journal of Management, IT and Social Sciences, 6(5), 158-166. https://doi.org/10.21744/irjmis.v6n5.713 
then there is a positive and significant effect between emotional intelligence $(\mathrm{X})$ and performance $(\mathrm{Y})$. Then, in the effect of job satisfaction $(\mathrm{M})$ on performance $(\mathrm{Y})$ has a t-statistic value of 2.796 and p-value of 0.005 , then there is a positive and significant effect between job satisfaction (M) and performance (Y).

\section{The Role of Job Satisfaction Mediation on the Effects of Emotional Intelligence on Performance}

The direct effect test results in Table 5.13 show that the value of the direct influence of emotional intelligence on performance in the model is 0.469 with $t$ statistics of 2.799 and a p-value of 0.005 . Meanwhile, the value of the coefficient of the direct influence of emotional intelligence on performance, before there is a mediating variable of job satisfaction that is equal to 0.783 with a value of $t$ statistics of 11.111 and a value of $P 0.000$. This value indicates that there is a significant influence of emotional intelligence variables on employee performance before mediating variables are included in the model.

The existence of job satisfaction as a mediating variable will have a different effect on the direct relationship of emotional intelligence to performance. Testing of job satisfaction as a mediating variable is done by calculating the value of Variance Accounted For (VAF).

Calculation of Variance Accounted For (VAF) requires the value of the coefficient of indirect effect and the coefficient of total effect (Hair et al., 2013). To calculate the indirect effect of emotional intelligence on employee performance, a multiplication coefficient of direct influence between the emotional intelligence coefficient on job satisfaction and job satisfaction on employee performance is calculated. The results are as follows:

Indirect Effect $=0.683 \times 0.0 .459=0.314$

The coefficient value of the indirect effect of emotional intelligence on employee performance through job satisfaction is 0.314. Furthermore, to determine the coefficient of the total effect, a calculation of the sum of the coefficients of direct influence of emotional intelligence on employee performance and the coefficient of indirect effect of emotional intelligence on employee performance through job satisfaction is calculated as follows:

Total Effect $=0.469+0.314=0.783$

The value of the total effect coefficient is 0.783 . By knowing the value of the coefficient of indirect influence and the coefficient of the total effect, then we can calculate the value of the Variance Accounted For (VAF) as follows:

$\mathrm{VAF}=($ Indirect Effect $) /($ Total Effect $)$

$=0.314 / 0.783$

$=0.401$

From the results of these calculations, the role of job satisfaction as a mediator in the influence of emotional intelligence on employee performance has a VAF value of 0.401 (40.1 percent). Based on these values, job satisfaction has a partial mediating role in the influence of emotional intelligence on employee performance. Emotional intelligence can affect employee performance directly or indirectly through job satisfaction. Therefore, it can be concluded that the hypothesis stating job satisfaction acts as a mediator between the relationship between emotional intelligence and proven employee performance.

\section{The Effect of Emotional Intelligence on Job Satisfaction}

Hypothesis testing conducted on the influence of emotional intelligence on job satisfaction in this study obtained results that emotional intelligence has a significant positive effect on job satisfaction. A positive and significant effect on emotional intelligence and job satisfaction indicates that the more emotionally intelligent the employee is, the higher the job satisfaction level will be. In research related to the impact of emotional intelligence on job satisfaction, AlHamami et al., (2015), states that when employees are involved and react to work and there is an emotional attachment to their work, then employees will feel satisfied with the job. Studies by Yoon (2016) and Kassim et al., (2016), state that the dimensions of emotional use and emotion regulation have a significant influence on job satisfaction. In line with the study, in this study the emotional intelligence variable has a significant influence on job satisfaction.

\section{The Effect of Emotional Intelligence on Performance}

Hypothesis testing conducted on the influence of emotional intelligence on performance in this study obtained results that emotional intelligence has a positive and significant effect on performance. A positive and significant effect on these two variables indicates that employees who are emotionally intelligent will have a positive influence on their 
performance. The results obtained related to the influence of emotional intelligence on performance in this study are in line with several similar studies that study the relationship of emotional intelligence on performance. A study by Shooshtarian et al., (2013), which states that workers with higher emotional intelligence will be more skilled in facilitating performance at work and have an awareness of the influence of emotions on behavior and results obtained. In these circumstances they can regulate emotions consistently to work responsibilities. Likewise, the results of a study conducted previously by Chaudry \& Usman (2011), which stated that employee performance at work is strongly influenced by competencies related to emotional intelligence. Suliman \& Al-Shaikh (2007) in Chaudry \& Usman (2011), argue that employees with high levels of emotional intelligence will contribute low to the emergence of interpersonal conflict, so it can be said that emotional intelligence can influence employee attitudes and behavior in organizing.

\section{The Effect of Job Satisfaction on Performance}

On the results of testing the job satisfaction hypothesis on performance in this study, the results show that there is a positive and significant relationship between the two. This positive and significant relationship indicates that the more employees feel satisfied with the job, the employee will show good performance at work. The effect of job satisfaction on performance, supported by previous studies in various fields of industries, which study the relationship between job satisfaction and performance that has results similar to this study. Antoncic \& Antoncic (2011), explained that employee work has a positive influence on work dimensions as well as a positive effect on company growth. A survey conducted by Bakan et al., (2014), of academic staff in Turkey shows that job satisfaction has a positive impact on job performance and job commitment. Perera \& Weerakkody (2016), conducted a study of non-executive workers in the Kalutara district of Sri Lanka, finding a positive relationship between job satisfaction and their performance.

\section{The Effects of Emotional Intelligence on Performance Mediated by Job Satisfaction}

The role of job satisfaction as a mediator has been proven in several similar studies in the relationship of emotional intelligence to performance. In this study, the test results on the indirect effect of job satisfaction variables show the results that job satisfaction has a partial role in partially mediating the influence of emotional intelligence on employee performance at BBPOM in Denpasar, so the hypothesis stating the influence of emotional intelligence on performance is mediated by job satisfaction can be accepted. Yoke \& Panatik (2016) and also research by Chin \& Yusoff (2017), that job satisfaction is an important stimulator that can affect the relationship between emotional intelligence on performance. Job satisfaction, in this case, becomes an important factor to consider as an effort to improve employee performance. By optimizing aspects or dimensions of job satisfaction employees are expected to have good acceptance and emotional control over how they deal with changes, job responsibilities, and have interactions or communication that is built either with external or internal parties as public service providers in the BBPOM in Denpasar to achieve an adequate service climate and provide quality services.

\section{Conclusion}

The results showed that there was a positive and significant influence by emotional intelligence on employee performance, and job satisfaction had a role to mediate the influence of these two variables. To improve performance in order to achieve excellent service as a public service provider, the things that need to be considered and improved are viewed from the dimensions of job satisfaction, namely how employees can view hard work and colleague responsibilities as motivation or positive encouragement in work. Other implications related to emotional intelligence in its influence on performance, namely an increase in the assessment and expression of emotions in themselves and the use of emotions, where employees can always use their common sense. Enhancing collaborative activities and training, especially in the internal environment, can improve employees' ability to understand and be sensitive to other people feelings.

\section{Research Limitation}

1) The scope of the research is carried out only in one public service organization, the BBPOM in Denpasar, amid the many public service organizations that are expected to further expand the scope of the research location so

Lestari, I. A. P. W., \& Wibawa, I. M. A. (2019). Job satisfaction mediating towards effect of emotional intelligence on performance. International Research Journal of Management, IT and Social Sciences, 6(5), 158-166. 
that it can be used to evaluate a broader and more comprehensive picture as well as varying sampling related the role of emotional intelligence and job satisfaction in improving employee performance.

2) This research depends on the results of the questionnaire so that respondents have the potential to give answers that are considered in accordance with certain values that can be accepted in their social environment, so that it can distort the average value for each variable.

3) This study only measures performance variables using three dimensions, namely task performance, adaptive performance, and contextual performance.

4) This research was conducted with a cross-sectional time plan, with the dynamics of change occurring in each period it is important to conduct ongoing research in the future.

\section{Conflict of interest statement}

The authors declared that they have no competing interest.

Statement of authorship

The authors have a responsibility for the conception and design of the study. The authors have approved the final article.

\section{Acknowledgments}

The authors would like to thank the editor of IRJMIS for their valuable time, support, and advice in completing the present research. 


\section{References}

Al-Hamami, N. M., Hashim, M. T., Songip, A. R., \& Al-Saeed, A. H. The Effects of Emotional Intelligence on Job Satisfaction.

Auer Antoncic, J., \& Antoncic, B. (2011). Employee satisfaction, intrapreneurship and firm growth: a model. Industrial Management \& Data Systems, 111(4), 589-607.

Bakan, I., Buyukbese, T., Ersahan, B., \& Sezer, B. (2014). Effects of Job Satisfaction on Job Performance and Occupational Commitment. International Journal of Management \& Information Technology, 9(1), 1472-1480. https://doi.org/10.24297/ijmit.v9i1.668

Bangun, R., Theresia, L., Lahuddin, A. H., \& Ranti, G. (2018). The influence of culture, job satisfaction and motivation on the performance lecturer/employees. In Proceedings of the International Conference on Industrial Engineering and Operations Management (pp. 2541-2552).

Barakat, H. (2015). Contemporary North Africa: issues of development and integration. Routledge. https://doi.org/10.4324/9781315650623

Chanana, M., \& Gupta, K. (2016). Quality of work life and its impact on job performance: a study of S.B.I \& HDFC banking professionals. International Research Journal of Management, IT and Social Sciences, 3(5), 16-24.

Chaudhry, A., \& Usman, A. (2011). An investigation of the relationship between employees' emotional intelligence and performance. African Journal of Business Management, 5(9), 3556-3562.

Cherniss, C. (2000). Emotional intelligence: What it is and why it matters. In annual meeting of the Society for Industrial and Organizational Psychology, New Orleans, LA (Vol. 15).

Chin, T. S., \& Yusof, R. M. (2017). Mediating Effects of Job Satisfaction in the Relationship Between Emotional Intelligence and Organisational Performance. Advanced Science Letters, 23(9), 8871-8873. https://doi.org/10.1166/asl.2017.9986

Curşeu, P. L., \& ten Brink, T. (2016). Minority dissent as teamwork related mental model: implications for willingness to dissent and group creativity. Thinking Skills and Creativity, 22, 86-96.

Dulewicz, V., \& Higgs, M. (2000). Emotional intelligence-A review and evaluation study. Journal of managerial Psychology, 15(4), 341-372.

Farrastama, D. N., Asmony, T., \& Hermanto, H. (2019). Effect of emotional intelligence on counterproductive work behavior with job stress as an intervening variable. International Journal of Social Sciences and Humanities, 3(1), 14-25. https://doi.org/10.29332/ijssh.v3n1.248

Hair, J. F., Ringle, C. M., \& Sarstedt, M. (2013). Partial least squares structural equation modeling: Rigorous applications, better results and higher acceptance. Long range planning, 46(1-2), 1-12.

Jamshed, S. (2018). Emotionally intelligent teams: can emotional intelligence enhance performance. Kuwait Chapter of the Arabian Journal of Business and Management Review, 7(1), 23-33.

Jeon, A. (2016). The effect of pre-flight attendants' emotional intelligence, emotional labor, and emotional exhaustion on commitment to customer service. Service Business, 10(2), 345-367.

Jung, H. S., \& Yoon, H. H. (2016). Why is employees' emotional intelligence important? The effects of EI on stresscoping styles and job satisfaction in the hospitality industry. International Journal of Contemporary Hospitality Management, 28(8), 1649-1675.

Kassim, S. I., Bambale, A. J., \& Jakada, B. A. (2016). Emotional Intelligence and Job Satisfaction among Lecturers of Universities in Kano State: Empirical Evidence. Journal of Education and Practice, 7(10), 53-59.

Kawiana, I. G. P., Dewi, L. K. C., Martini, L. K. B., \& Suardana, I. B. R. (2018). The influence of organizational culture, employee satisfaction, personality, and organizational commitment towards employee performance. International Research Journal of Management, IT and Social Sciences, 5(3), 35-45.

Kurniawan, L. S. (2019). Emotional intelligence and marital decision. International Journal of Health Sciences, 3(2), 11-20. https://doi.org/10.29332/ijhs.v3n2.287

Mishra, P. S., \& Mohapatra, A. D. (2010). Relevance of emotional intelligence for effective job performance: An empirical study. Vikalpa, 35(1), 53-62. https://doi.org/10.1177\%2F0256090920100104

Na-Nan, K., Chaiprasit, K., \& Pukkeeree, P. (2018). Factor analysis-validated comprehensive employee job performance scale. International Journal of Quality \& Reliability Management, 35(10), 2436-2449.

Narayana, M. S., \& Narasimham, B. V. (2018). Dynamics of Emotional Intelligence and Job Performance. International Journal of Emerging Research in Management and Technology, 7(1), 57-71.

Pant, I., \& Yadav, R. K. (2016). Impact of emotional intelligence on the job performance of employee. International Research Journal of Management, IT and Social Sciences, 3(1), 7-14.

Perera, M. D. S. H., \& Weerakkody, W. A. S. (2016). Impact of job satisfaction on job performance of non-executive

Lestari, I. A. P. W., \& Wibawa, I. M. A. (2019). Job satisfaction mediating towards effect of emotional intelligence on performance. International Research Journal of Management, IT and Social Sciences, 6(5), 158-166.

https://doi.org/10.21744/irjmis.v6n5.713 
employees in hotel industry: with reference To Kalutara district. Kelaniya Journal of Human Resource Management, 11(1). http://doi.org/10.4038/kjhrm.v11i1.27

Rangarajan, R., \& Jayamala, C. (2014). Impact of emotional intelligence on employee performance-an epigrammatic survey. Sumedha Journal of Management, 3(1), 76.

Saputra, L. A. A., Surati, -, \& Saufi, A. (2019). Mediation role of job satisfaction towards effect of conflict roles on organizational commitment. International Journal of Social Sciences and Humanities, 3(2), 165-175. https://doi.org/10.29332/ijssh.v3n2.308

Shooshtarian, Z., Ameli, F., \& Amini Lari, M. (2013). The effect of labor's emotional intelligence on their job satisfaction, job performance and commitment. Iranian Journal of Management Studies, 6(1), $27-43$. https://dx.doi.org/10.22059/ijms.2013.30123

Suliman, A. M., \& Al-Shaikh, F. N. (2007). Emotional intelligence at work: Links to conflict and innovation. Employee Relations, 29(2), 208-220.

Vratskikh, I., Al-Lozi, M., \& Maqableh, M. (2016). The impact of emotional intelligence on job performance via the mediating role of job satisfaction. International Journal of Business and Management, 11(2), 69.

Widiani, N. P., Putri, A. M. A. D., Sari, M. M. R., \& Wirajaya, I. G. A. (2019). The effect of love of money and emotional intelligence on employee performance with organizational citizenship behavior as mediating variable. International Research Journal of Engineering, IT \& Scientific Research, 5(1), 39-49. https://doi.org/10.21744/irjeis.v5n1.596

Wiguna, I. P. I., \& Yadnyana, K. (2019). The role of working experience moderating the effect of emotional intelligence, intellectual intelligence, and spiritual intelligence on the ethical decision of tax consultants in Bali area. International Research Journal of Management, IT and Social Sciences, 6(3), 18-28. https://doi.org/10.21744/irjmis.v6n3.624

Wong, C. S., \& Law, K. S. (2002). The effects of leader and follower emotional intelligence on performance and attitude: An exploratory study. The leadership quarterly, 13(3), 243-274. https://doi.org/10.1016/S10489843(02)00099-1

Yoke, L. B., \& Panatik, S. A. (2016). Emotional intelligence and job performance. International Business Management, 10(6), 806-812. 